\title{
Anesthetic management for transfusion-free Rastelli's procedure in a pediatric Jehovah's Witness patient
}

\author{
Sun-Hye Kang, Inkyung Song, Joo-Eun Kang, Ji-Hyun Lee, and Jin-Tae Kim \\ Department of Anesthesiology and Pain Medicine, Seoul National University Hospital, Seoul, Korea
}

Transfusion-free cardiac surgery in small cyanotic children is challenging to anesthesiologists because of cardiopulmonary bypass (CPB)-induced hemodilution and coagulopathy. Redocomplex cardiac procedures increase the incidence and volume of the transfusion [1]. Rastelli's procedure is a high risk procedure (RACHS; risk adjustment in congenital heart surgery category 4) and usually requires a blood transfusion.

We present a 27 month-old girl $(78.5 \mathrm{~cm}$ height and $7.7 \mathrm{~kg}$ weight) who was admitted for Rastelli's operation. The patient underwent the modified Blalock-Taussig shunt and patent ductus arteriosus closure 1 year ago without a transfusion.

Her parents were Jehovah's Witnesses. They refused a perioperative blood transfusion, which included packed red blood cells, fresh frozen plasma, platelets, and albumin. They also refused usage of a cell saver. The anesthesiologist explained acute normovolemic hemodilution (ANH) and the parents agreed to ANH with the understanding that the collected autologous blood was not separated from the patient.

One week before the surgery, recombinant human erythropoietin (2000 IU) was administered three times per week and iron sucrose was administered every day to stimulate the patient's blood cell production. After treatment, the hematocrit (Hct) increased from 47.2 to $49.1 \%$. Platelet count and coagulation factors were within the normal range.

After induction of anesthesia, $10 \mathrm{mg} / \mathrm{kg}$ tranexamic acid was infused for 30 minutes, then a continuous infusion was started at a rate of $5 \mathrm{mg} / \mathrm{kg} / \mathrm{hr}$. Cerebral oximetry (INVOS 5100, Somanetics, NY, USA) monitoring was started and the initial regional cerebral oxygen saturation $\left(\mathrm{rSO}_{2}\right)$ values were $48 / 47 \%$ on the right/left sides. For ANH, $190 \mathrm{ml}$ of whole blood was withdrawn from the patient's central line to the blood bag (single-320 ml blood bag, Greencross, Seoul, Korea), which contained 44.8 $\mathrm{ml}$ of citrate phosphate dextrose adenine. The same volume of hydroxyethyl starch (Voluven ${ }^{\circledR}$, Fresenius Kabi, Bad Homburg, Germany) was infused while collecting the blood. The Hct decreased from 45 to $35 \%$ after $\mathrm{ANH}$. The changes in $\mathrm{rSO}_{2}$ were $<10 \%$ from baseline, and blood lactate was within the normal range during $\mathrm{ANH}$.

A high-performance, low prime volume oxygenator (RX- $05^{\mathrm{TM}}$, Terumo, Tokyo, Japan) was used and the arterial line filter was excluded to minimize the priming volume for CPB. During $\mathrm{CPB}$, the Hct and $\mathrm{pH}$ ranged from 24 to $28 \%$, and from 7.23 to 7.33 respectively. Intraoperative changes in blood lactate during surgery were within the normal range.

After weaning from $\mathrm{CPB}$, the collected autologous blood was transfused after protamine administration.

Total operation time was $7 \mathrm{~h}$ and 20 minutes. The estimated blood loss and urine output was 130 and $720 \mathrm{ml}$. The patient received $190 \mathrm{ml}$ of autologous blood and $215 \mathrm{ml}$ of other fluids. The hematologic data are shown in Table 1.

Erythropoietin and iron sucrose were re-started. The lowest hemoglobin concentration in the ward was $7.6 \mathrm{~g} / \mathrm{dl}$, which increased to $9.4 \mathrm{~g} / \mathrm{dl}$ on day 13 after surgery. The patient was discharged on postoperative day 19 with oral iron therapy and no complications.

Three important issues must be considered for transfusionfree surgery. First, the volume of red blood cells should be increased before surgery. Second, the volume of blood loss should

Corresponding author: Jin-Tae Kim, M.D., Department of Anesthesiology and Pain Medicine, Seoul National University Hospital, 101, Daehakro, Jongno-gu, Seoul 110-744, Korea. Tel: 82-2-2072-2465, Fax: 82-2-747-5639, E-mail: kimjintae73@dreamwiz.com

(c) This is an open-access article distributed under the terms of the Creative Commons Attribution Non-Commercial License (http:// creativecommons.org/licenses/by-nc/3.0/), which permits unrestricted non-commercial use, distribution, and reproduction in any medium, provided the original work is properly cited. 
Table 1. Changes in Hematological Data

\begin{tabular}{lcccc}
\hline & $\begin{array}{c}\text { Hemoglobin } \\
(\mathrm{g} / \mathrm{dl})\end{array}$ & $\begin{array}{c}\text { Hct } \\
(\%)\end{array}$ & $\begin{array}{c}\text { WBCs } \\
\left(\times 10^{3} \mu \mathrm{l}\right)\end{array}$ & $\begin{array}{c}\text { Platelets } \\
\left(\times 10^{3} / \mu \mathrm{l}\right)\end{array}$ \\
\hline Admission & 15.8 & 47.2 & 4.71 & 152 \\
Before surgery & 16.4 & 49.1 & 6.17 & 265 \\
After ANH & $\mathrm{N}$ & 35 & $\mathrm{~N}$ & $\mathrm{~N}$ \\
CPB off & $\mathrm{N}$ & 26 & $\mathrm{~N}$ & $\mathrm{~N}$ \\
ICU initial & 10.3 & 31.3 & 12.15 & 135 \\
POD \#1 & 10.5 & 31.2 & 12.66 & 130 \\
POD \#2 & 9.2 & 27.7 & 15.43 & 107 \\
POD \#11 & 7.6 & 24.1 & 13.01 & 394 \\
POD \#17 & 9.4 & 29.9 & 9.22 & 436 \\
\hline
\end{tabular}

Hct: hematocrit, WBC: white blood cell, CPB: cardiopulmonary bypass, ICU: intensive care unit, POD: postoperative day, N: no data.

be minimized during surgery. Third, bleeding should be prevented after surgery.

The patient received erythropoietin and simultaneous oral iron supplementation preoperatively. These have been shown to promote red blood cell production and reduce allogenic blood transfusion in children undergoing open heart surgery [2].

ANH is a blood conservation method to collect a patient's red blood cells before or just after induction of anesthesia. In a previous report, the non-transfusion rate of Rastelli's procedure was only $17 \%$, but it increased to $75 \%$ following autologous blood donation [3].

The ANH-induced decrease in Hct may have impaired tissue oxygenation. Therefore, target Hct was determined to be $35 \%$, and $190 \mathrm{ml}$ of blood was collected as calculated. During ANH, safety was assessed using vital signs, lactate values, and $\mathrm{rSO}_{2}$, which is a useful indicator of trends in cerebral oxygenation [4].

Complex transfusion-free procedures can be accomplished safely in pediatric patients with a miniaturized CPB system for low priming volume [5]. In our case, we used a neonatal $\mathrm{CPB}$ system (Heart-Lung machine HL $30^{\mathrm{TM}}$, Maquet, Hirrlingen, Germany) to reduce hemodilution and maintain adequate oxygen supply.

Additionally, tranexamic acid was continuously infused during the operation to reduced intra- and post-operative blood loss.

In summary, we performed a transfusion-free Rastelli's procedure in a child weighing $7.7 \mathrm{~kg}$. We conclude that multidisciplinary approaches, including perioperative erythropoietin, $\mathrm{ANH}$, a low-prime $\mathrm{CPB}$ circuit, and tranexamic acid, enable high risk transfusion-free cardiac surgery in children.

\section{References}

1. Jenkins KJ, Gauvreau K, Newburger JW. Consensus-based method for risk adjustment for surgery for congenital heart disease. J Thorac Cardiovasc Surg 2002; 134: 110-8.

2. Sonzogni V, Crupi G, Poma R, Annechino F, Ferri F, Filisetti P, et al. Erythropoietin therapy and preoperative autologous blood donation in children undergoing open heart surgery. Br J Anaesth 2001; 87: 429-34.

3. Takahashi Y, Tatsuno K, Kikuchi T. Open heart surgery with bloodless priming for cyanotic congenital heart diseases--the role of autologous blood donation after induction of anesthesia. Nihon Kyobu Geka Gakkai Zasshi 1996; 44: 1075-81.

4. Schwarz G, Litscher G. Transcranial cerebral oximetry, transcranial Doppler sonography, and heart rate variability: useful neuromonitoring tools in anaesthesia and intensive care? Eur J Anaesthesiol 2002; 19: 543-9.

5. Miyaji K, Kohira S, Miyamoto T, Nakashima K, Sato H, Ohara K, et al. Pediatric cardiac surgery without homologous blood transfusion, using a miniaturized bypass system in infants with lower body weight. J Thorac Cardiovasc Surg 2007; 134: 284-9. 